\title{
WOMEN ENTREPRENEURSHIP AND INNOVATIONS: A CRITICAL ANALYSIS
}

\section{Lalan Dwibedi}

Department of Management, TU, Thakur Ram Multiple Campus, Birgunj, Nepal

\author{
E-mail:dwivedylalan@gmail.com
}

\begin{abstract}
Increased female entrepreneurial activity heralds a progress for women's rights and optimization of their economic and social living index. Women entrepreneurship is synonymous with women empowerment. Parallel to the male counterparts, female entrepreneurs are catalytic in job creation, innovation and more than tangible contribution to the GNP of the country. An economy thrives when women get a level playing field as men. Innovation works as a catalyst or an instrument for entrepreneurship. Despite all the social hurdles stand tall from the rest of the crowd and are applauded for their achievements in their respective field. The transformation of social fabric of the society, in terms of increased educational status of women and varied aspirations for better living, necessitated a change in the life style of women. This paper endeavors to explore studies related to women entrepreneurship and innovation and how it leads to success and growth of an enterprise.
\end{abstract}

\section{Key words}

Women entrepreneurship; innovation; transformation; entrepreneur, economy

\section{Introduction}

Entrepreneurship is the process of assembling necessary factors of production consisting of human, physical, and information resources and doing so in an efficient manner and entrepreneurs as those who put people together in particular ways and combine them with physical capital and ideas to create a new product or to produce an existing. Entrepreneurship is considered as a factor of production, linked to innovation and risk taking, where entrepreneurial compensations are tied to uncertainty and profits. Women entrepreneurship has a tremendous potential in empowering women and transforming society. It has been recognized as an important source of economic growth. Women entrepreneurs create new job for themselves and others, thus contributing to the solution to organization and business problem. The emergence of women on the economic scene 
as entrepreneurs is a significant development in the emancipation of women and securing them a place in the society, which they have all along deserved. The hidden entrepreneurial potential of women has gradually been changing with the growing sensitivity to the role of economic status in the society. Premalatha (2010) describes women are the architects of human society. Women are a significant force in the entrepreneurial world, as they make a noteworthy contribution to the economic development, and women-owned businesses are critical to economic prosperity. Women entrepreneur is the one who starts business and manages it independently and tactfully, taking all the risks at the same time facing the challenges boldly with the determination to be successful. Women entrepreneurship is an economic activity who think of a business enterprise, initiate it, organize and combine all the factors of production, operate the enterprise and undertake the risks and handle the economic uncertainty involved in running a business enterprise. Women entrepreneurship has crossed the stage of transition and it is finally in flight, but it still has a long way to go and emerge as successful business giant.

Ganesamurthy (2007) defines women entrepreneur as a confident, innovative and creative women capable of achieving self-economic independence individually or in collaboration, generates employment opportunities for others though initiating, establishing and running the enterprise by keeping pace with her personal family and social life. The economists note that educating more women in developing countries is likely to raise the productive potential of an economy significantly. Thus, women entrepreneur's means making the women self-reliant giving her the liberty to make choices in her life and providing her with information and knowledge to take decisions. Education and employment are the only two methods that can empower them.

Women entrepreneurship is an essential part of the human resource development. Women have become aware of their existence, their rights and their work situation due to the growing industrialization, urbanization and social legislation and with the spread of higher education \& awareness, the emergence of women owned businesses are speedily increasing in the economies of almost all countries. The examples assumes that women explore the prospects of starting a new enterprise, undertake risks, introduce new innovation, coordinate administration \& control of business \& provide effective leadership in all aspects \& have proved her footage in the male dominated business arena . The disconnect between the two spheres of everyday existence, the proliferation of loci of identity on one hand and the endeavor to combine so many elements (times, relational style, etc.) on the other, is depicted as an identity resource for female entrepreneurs because it give rise to opportunities and the ability to developing specific organizational, relational and institutional skills (Bruni et al., 2004). What we need is an entrepreneurial society in which innovation and women entrepreneurship are normal, steady and continuous. Just as management has become the specific organ of all contemporary institutions, and the integrating organ of our society of organizations, so innovation and entrepreneurship have to become an integral life-sustaining activity in our organizations, our economy and our society.

\section{Women entrepreneurship in India}

Ganesamurthy (2007) defines women entrepreneur as an enterprise owned and controlled by women and having a minimum financial of 51 percent of the capital and giving 51 per cent of the employment generated in the enterprise of women. It has been globally recognized that women empowerment can be well paying strategy for overall economic and social development. This has resulted in significant changes in the approach to assist women in continuum ranging from welfare to development. 
Entrepreneurship development among women is one activity that promises encouraging results. By motivating, training and assisting women towards forming and running business ventures, it may be possible to tackle many of gender issues. Jahanshahi et al. (2010) stresses economic globalization has encouraged the expansion of female business ownership. Women owned businesses are highly increasing in the economy of almost all countries. The hidden entrepreneurial potentials of women have gradually been changing with the growing sensitivity to the role and economic status in the society.

Women entrepreneur is a person who accepts challenging role to meet her personal needs and become economically independent. A strong desire to do something positive is an inbuilt quality of entrepreneurial women, who is capable of contributing values in both family and social life. With the advent of media, women are aware of their own traits, rights and also the work situations. Innovation is defined as the implementation of a new or significantly improved product (good or service) or processes, or a new marketing method or a new organizational method in business practices, work place organization or external relations.

Vishwanathan (2001) studied the opportunities and challenges for women in business. The strategy of self- help groups was used to empower the vulnerable and powerless poor women through DWCRA. Awareness programmes and group activities were provided and emphasis was made on setting up of local "skill exchanges" that helped women to improve their economic status. The author cited "Indira Mahila Yojana" which had the basic principle in its scheme that would lead to economic empowerment which would improve the family relationship and domestic work culture leading to social empowerment, more equitable participation of women in family decision making helping them acquire leadership qualities and political empowerment.
Various statistics show that even during the years of economic crisis and recession, the one robust sector providing economic growth, increased productivity and employment has been that of Small sized enterprises (SMEs).

\section{Women entrepreneurship in Nepal}

Comparatively little information has been available about the problems faced by women in Nepal starting businesses, whether in the light of gender disparities or the kinds of interventions needed to support women in developing ventures where increasing number of women entrepreneurs are promoting economic growth through their individual efforts.

While women entrepreneurs are struggling to improve their lives in an environment of high unemployment and political unrest over the past ten years, more and more Nepalese women have entered into private enterprise.

In line with the 1995 Beijing declaration, the government adopted the rhetoric of women's participation, and introduced various genderbased initiatives, increased microfinance support systems, and created an opening for the introduction of gender policies and programmes in many government bodies and NGOs. Measures to address gender-specific barriers to women's entrepreneurship include gender-equity measures, such as equal access for both men and women to education and skill-training in business management, which were legislated under the Tenth Five-Year Plan. But, due to the violent insurgency by the Maoist Party of Nepal for overall political instability, the means to enact the legislation were unavailable; even men made few gains under the legislation.

It is currently estimated that in Asia, nearly one-third of new small enterprises are being set up by women, and in many cases these businesses are creating employment faster than the countries' domestic averages (Thapa, 2004). It is estimated that over 7,00o 
women entrepreneurs are now registered and more than 500,000 are involved in business activities country-wide. However, although their combined contribution to the national economy is estimated at 40 percent of the GDP, they remain the largest underrepresented group in terms of visibility as owners of enterprises (De Gobbi, 2005).

It is very difficult to estimate the current number of women entrepreneurs in Nepal due to the absence of up-to-date statistics and gender data. In addition, the statistics do not reveal who actually controls and runs women's businesses: even though women may be officially registered as owners of a business, in frequent cases it is the husband or father who is operating the business. This 'surrogate entrepreneurship' a phrase coined by Ganesan (2003) makes the task of accurately capturing the number of actual women entrepreneurs very difficult. Although women entrepreneurs have always been common in some ethnic groups especially in Newar, Sherpa and Gurung communities, the idea of women in business has only recently become more common across the country (Tuladhar, 1996). On the average, female-headed enterprises earn about two-thirds of what male-headed enterprises earn annually, and working hours tend to be at least three to four hours longer each day for women compared with men, due to the additional responsibilities women have in the home. These factors severely limit women's abilities to lead flourishing and profitable businesses.

It may be noted that although statistics are lacking, the number of women entrepreneurs either in absolute or relative terms has not reached the critical mass necessary to make an impact on the economic system, or to raise awareness in the country of the role women can take in the workplace and wider society. The subtle manifestation of the gender phenomenon is often reflected in the size of the business, product line, growth, composition, and management. A typical woman entrepreneur's enterprise is very small in traditional manufacturing, small shop or informal vending with low turnovers, a low number of employees and no professional assistance (Acharya, 2000).

\section{Women entrepreneurship and innovation}

Schumpeter defines entrepreneurs as individuals that carry out new combinations (i. e. innovations). Schumpeter distinguishes four roles in the process on innovation; the inventor, who invents a new idea, the entrepreneur who commercializes this new idea; the capitalist, who provides the financial resources to the entrepreneur increasing in the economies of almost all countries. The hidden entrepreneurial potentials of women have gradually been changing with the growing sensitivity to the role and economic status in the society (as cited by Stam, 2008).

Yusuf (2007) predicts that the country which will lead in the $21^{\text {st }}$ century will be one which implements innovations- Meta ideassupporting the production of new ideas in the private sector. Bulsara et al. (2009) Innovation is the introduction of new ideas, goods, services and practices which intended to be useful (though a number of unsuccessful innovations can be found throughout history). The main driver for innovation is often the courage and energy to better the world. An essential element for innovation is its application in a commercially successful way. Innovation has punctuated and changed human history (consider the development of electricity, steam engines, motorvehicles etc.). Orhan \& Scott (2001) cite that academicians and government appear to be concentrating and encouraging entrepreneurship because it symbolizes innovation and a dynamic economy. Female entrepreneurs have been identified as a major force for innovation and Job creation and therefore much research about women business owners has concentrated on their motivation to become entrepreneurs (Nagar, 2008). 
Countries which do not capitalize on the full potential of one half of their societies are misallocating their human resources and compromising their competitive potential. Women entrepreneurs are reported to be growing at a faster rate than the economy as a whole in several countries. Their contribution could become even more significant if their potential is fully tapped and it is possible only when various obstacles and restrictions are removed. India stands as one of the most developing countries across the world, the economist to a great extent, have realized the potentialities of women. Gujarat state welcomes women entrepreneur and its innovation in India where women have flourished with hard work, dedication and innovation. Lijjat Papad (a handmade thin, crisp circular shaped Indian food, served as an accompaniment in Indian meals) is an example of a small group of seven women came together to start a venture for sustainable livelihood using the only skill they had, i.e. cooking. It is entrepreneurial organization to have built up and sustained the trust, productivity and the expectations of the customers.

\section{Conclusion}

Today we are in a better position wherein women participation in the field of entrepreneurship is increasing at a considerable rate. Efforts are being taken at the economy as brought promise of equality of opportunity in all spheres to the women and laws guaranteed equal rights of participation in political process and equal opportunities and rights in education and employment were enacted. But unfortunately, the government sponsored development activities have benefited only a small section of women i.e. the urban middle class women. At this juncture, effective steps are needed to provide entrepreneurial awareness, orientation and skill development programs to women. The role of Women entrepreneur in economic development is also being recognized and steps are being taken to promote women entrepreneurship. Re- surgence of entrepreneurship is the need of the hour emphasizing on educating women strata of population, spreading awareness and consciousness amongst women to outshine in the enterprise field, making them realize their strengths, and important position in the society and the great contribution they can make for their industry as well as the entire economy. Women entrepreneurship must be molded properly with entrepreneurial traits and skills to meet the changes in trends, challenges global markets and also be competent enough to sustain and strive for excellence in the entrepreneurial arena. If every citizen works with such an attitude towards respecting the important position occupied by women in society and understanding their vital role in the modern business field too, then very soon we can pre-estimate our chances of out beating our own conservative and rigid thought process which is the biggest barrier in developmental process of our country.

\section{References}

Acharya, M. (200o). Statistical profile of Nepalese women: A critical review of the Status of women in Nepal, (Vol. I, Part I). Kathmandu: CEDA.

(1981). The status of women in Nepal, (Vol. II, Part 6). Kathmandu: CEDA.

Bowen, D. D. \& Hirsch, R. D. (1986). The female entrepreneur: A career development perspective. Academy of Management Review, 11( 2), 393-407.

Bruni, A., Gherardi, S. \& Poggio, B. (2004). Entrepreneur-mentality, gender and the study of women entrepreneurs. Journal of Organizational Change Management 17(3), 256.

Bulsara, H. P., et al. (2009). Women entrepreneurship in India: A case study of phoenix soft toys creation. PCTE Journal of Business Management, 6(1)........

(2009). Techno-innovation to techno entrepreneurship through technology business incubation in India: An exploratory 
study. Asia Pacific Journal of Innovation and Entrepreneurship, 3(1)........

De Gobbi, M. (2005). Nepal and Pakistan micro finance and micro enterprises development $\mathcal{E}$ their contribution to the economic empowerment of women. SEED working paper no. 69, Geneva.

Ganesamurthy, V. S. (2007). Economic empowerment of women. New Delhi: New Century Publications.

Ganesan, S. (2003). Status of women entrepreneurs in India. New Delhi: Kanishka Publishers.

Jahanshahi, A. A., \& Pitamber, B. K. (2010). Issues and challenges for women entrepreneurs in global scene, with Special Reference to India. Australian Journal of Basic and Applied Sciences, 4(9), 4347-4356.

Nagar, N. S. (2008). Women and employment. New Delhi: Vista International Publishing House.

Orhan, M., \& Scott, D. (2001). Why women enter into entrepreneurship: An explanatory model. Women Management Review 16(5), 232- 243.
Premalatha, U. M. (2010). An empirical study of the impact of training and development on women entrepreneurs in Karnataka. The IUP Journal of SoftSkills,49(3).

Stam, E. (2008). Entrepreneurship and Innovation Policy. Jena Economic

Research Papers.......

Yusuf, S. (2007). From creativity to innovation. World Bank policy research working paper 4262 .

Thapa, A. (2004). On women's enterprise and regional cooperation in SAARC. Kathmandu: spotlight

Tuladhar, J. (1996). Factor affecting women entrepreneurs in small and cottage industries in Nepal. ILO-SIDA, Kathmandu.

Vishwanathan, R. (2001). Opportunities and challenges for women in business. Retrieved from http://indiatogether.org/women/ business/renuka.htm on 25th September, 2015. 